\title{
Evaluation of Instructional Technologies Course from the Perspective of Pre-service Teachers
}

\section{Öğretmen Adaylarının Bakış Açısından Öğretim Teknolojileri Dersine Yönelik Bir Değerlendirme}

\author{
Ulaş İLiC ${ }^{l}$
}

\begin{abstract}
${ }^{I}$ Sorumlu Yazar, Arş. Gör. Dr., Bilgisayar ve Öğretim Teknolojileri Eğitimi Bölümü, Eğitim Fakültesi, Pamukkale Üniversitesi, Türkiye, uilic@pau.edu.tr, (https://orcid.org/0000-00034213-8713)
\end{abstract}

Geliş Tarihi: 22.03.2021

Kabul Tarihi: 28.10.2021

\begin{abstract}
As of the 2018-2019 academic year, teacher training undergraduate programs have been reorganized in partnership with Turkish CHE and Ministry of National Education. One of the technology-related courses in this program is the Instructional Technologies course. In this study, it is purposed to examine the opinions of pre-service teachers about Instructional Technologies course. For this aim, the research was carried out in the descriptive qualitative research design. 101 pre-service teachers participated in the research in spring term of 2018-2019 academic year. Criterion sampling method was employed in the selection of the participants. Data were collected from these participants before and after the course through the forms generated by the researcher. The obtained data were analyzed through the qualitative data analysis program. According to the results, expectations of students was satisfied at the end of the semester and that the course contributed to them in terms of using the instruments related to information and communication technologies. Besides, it was determined that the pre-service teachers considered this course necessary. It is thought that the findings will be useful in terms of examining the situation of the Instructional Technologies course in the new curriculum for prospective teachers.
\end{abstract}

Keywords: Instructional Technologies course, instructional technology, pre-service teachers.

ÖZ

2018-2019 öğretim yılından itibaren geçerli olmak üzere öğretmen yetiştirme lisans programları, YÖK ve MEB ortaklığında yeniden düzenlenmiştir. Bu programda yer alan teknoloji konulu derslerden biri de Öğretim Teknolojileri dersidir. Bu çalışmada öğretmen adaylarının Öğretim Teknolojileri dersine yönelik görüşlerinin incelenmesi hedeflenmiştir. Söz konusu amaç doğrultusunda çalışma, betimleyici nitel araştırma deseni ile gerçekleştirilmiştir. Araştırmaya 2018-2019 öğretim yılı bahar döneminde 101 öğretmen adayı katılmıştır. Katılımcıların seçiminde ölçüt örnekleme yöntemi işe koşulmuştur. Bu katılımcılardan ders öncesinde ve ders sonrasında araştırmacı tarafından geliştirilen formlar ile veri toplanmıştır. Ulaşılan veriler nitel veri analizi programı ile analiz edilmiştir. Araştırmadan elde edilen sonuçlara göre katılımcıların beklentilerinin dönem sonunda karşılandığı ve dersin kendilerine bilgi ve iletişim teknolojileri araçlarını kullanma bağlamda katkı sağladığı bulunmuştur. Buna ek olarak dersin öğretmen adayları tarafından gerekli görüldüğü belirlenmiştir. Ulaşılan bulguların, yeni öğretim programında yer alan Öğretim Teknolojileri dersinin durumunu öğretmen adayları açısından irdeleme bağlamında yararlı olacağı düşünülmektedir.

Anahtar Kelimeler: Öğretim Teknolojileri dersi, öğretim teknolojisi, öğretmen adayları. 


\section{INTRODUCTION}

Technology has become indispensable in every aspect of our lives. One of these aspects is the education. The education requires implementing the current technological instruments owing to its dynamic nature. The teachers who will fulfill this requirement called as instructional technologies, Information and Communication Technologies (ICT), or Computer-Assisted Education (CAE) should also have sufficient skills in this context. At this point, it is important to enable the pre-service teachers to acquire the related competence before starting the profession (Kirschner, Wubbels \& Brekelmans, 2009). It is observed that ICT competencies are tried to be provided to the pre-service teachers through such courses as Computer II, Instructional Technologies and Material Design (ITMD), and Instructional Technologies at different times (YÖK, 2007, 2018a, 2018b). In this context, it is essential to examine the contents of these courses in detail.

\subsection{Computer II Course}

Computer II course is one of the courses in which the skills related to basic ICT are tried to be acquired in the Faculty of Education curriculums in Turkey. The basic concepts of CAE, its elements, fundamentals, advantages and limitations of CAE, its practice, and common formats in CAE are covered in the course. This course is lectured for 4 hours per week (2 theoretical hours and 2 practice hours). The necessity of taking Computer II course in this form as compulsory is considered as important in the context of the acquisition of the skills related to basic computer use for the pre-service teachers. In addition, when it is considered that these skills must be included by the individual so as to actively apply the CAE (Engin, Tösten \& Kaya, 2010), the importance of Computer II course emerges. It is also observed that the pre-service teachers have positive thoughts about the Computer II course in the studies which include the related course or are carried out within the context of this course (Birişçi \& Karal, 2011; Çuhadar, 2010; Çukurbaşı \& Kıyıcı, 2018a, 2018b; Haseski \& İlic, 2020; Mıhcı Türker \& Pala, 2018).

\subsection{Instructional Technologies and Material Design Course}

The departments in faculty of education that train teachers at primary and secondary level were amended through a decision taken by Council of Higher Education (CHE) on July 21, 2006. This change was caused by the desire to achieve common standards in the faculties of education in the context of defining the undergraduate learning outcomes of the European Higher Education Area. The new curriculum came into effect in the 2006-2007 academic year (YÖK, 2007). The program includes several compulsory common courses. One of these courses is ITMD. The purpose of the course is defined by YÖK (2007) as follows:

"Concepts related to instructional technology, characteristics of several instructional technologies, the place and use of instructional technologies in the teaching process, determining the technology needs of the school or classroom, making and executing appropriate technology planning, developing two and three dimensional materials through instructional technologies, developing teaching materials (worksheets, designing activities, overhead transparencies, slides, visual media (VCD, DVD) materials, computer-based tools), examining the educational software, assessing the instructional materials in several qualities, internet and distance education, visual design principles, research on the effectiveness of teaching materials, examining the use of instructional technology in Turkey and the world." 


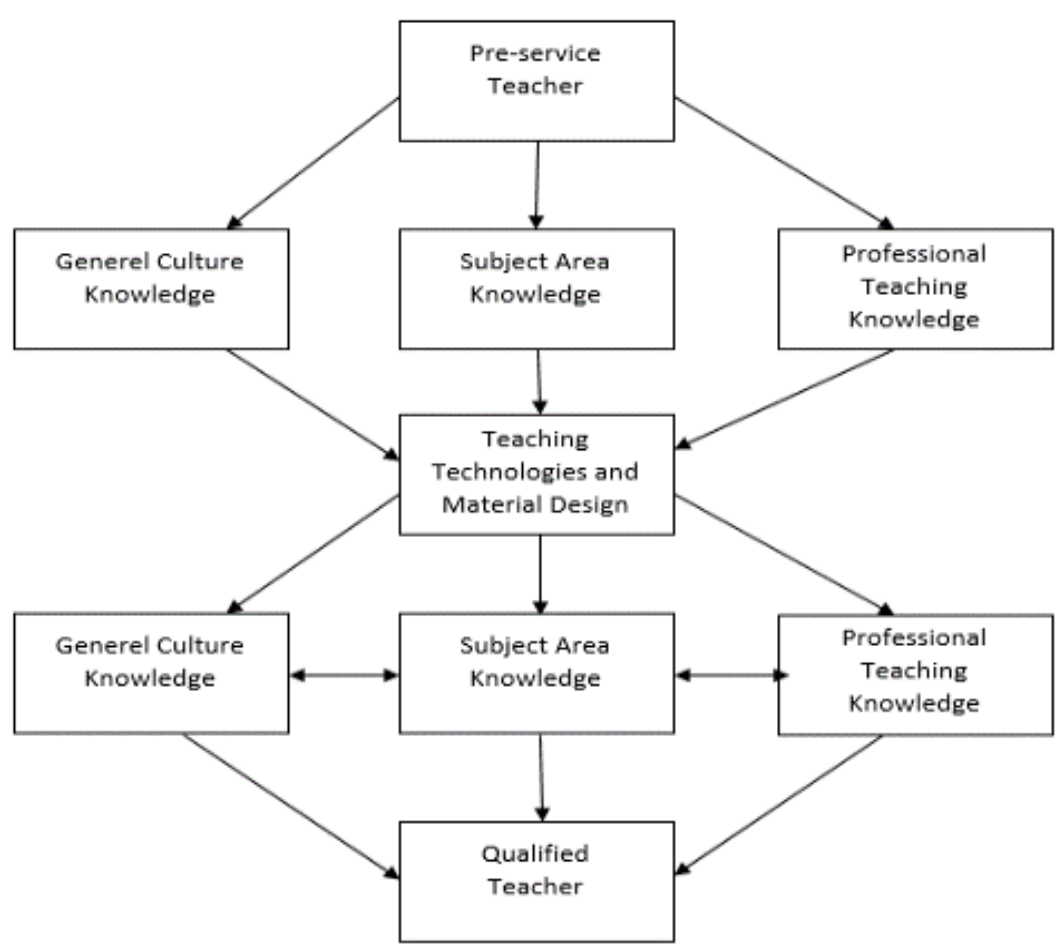

Figure 1. The Lecture Process of ITMD Course in Faculties of Education (Gündüz \& Odabaşı, 2004)

When the purpose of the ITMD course and Figure 1 are examined, it is concluded that the course can be efficiently processed only with the pre-service teachers who are at a certain level. According to this, the students take general culture, subject area knowledge, and professional teaching knowledge courses in their first years, and then they can attend in the process of producing materials by using instructional technologies through ITMD. When the literature is reviewed, it is observed that the pre-service teachers react positively to the course, that the course contributes to them and that the course is necessary (Acer, 2011; Kolburan \& Geçer, 2010; Saka \& Saka, 2005; Uzunöz, Aktepe \& Gündüz, 2017; Yaman, 2007; Yazar, 2015; Yelken, 2009).

\subsection{Instructional Technologies Course}

25 teacher training undergraduate programs have been reorganized in cooperation with Turkish CHE and Ministry of National Education as of 2018-2019 academic year so as to meet the compliance, quality, and accreditation criteria of the Bologna process in the field of European Higher Education. One of the courses in the curriculum within the framework of this regulation is Instructional Technologies. The content of the course is defined under the title of undergraduate program course contents of the curriculum file published by CHE through the explanations as follows (YÖK, 2018b):

"Information technologies in education; instructional process and classification of instructional technologies; theoretical approaches to instructional technologies; new approaches in learning approaches; contemporary literacies; instructional technologies as instruments and materials; design of instructional materials; designing thematic instructional materials; creating field-specific object warehouse, assessment criteria of instructional material." 
Table 1. Distribution of The Course According to The Undergraduate Programs and Semesters

\begin{tabular}{lll}
\hline & $3^{\text {rd }}$ Semester & $4^{\text {th }}$ Semester \\
\hline Undergraduate & Physical Education and Sports & German Language Teaching \\
Program & French Language Teaching & Arabic Language Teaching \\
Elementary Mathematics & Biology Education \\
Education & \\
English Language Teaching & Geography Education \\
Chemistry Education & Philosophy Education \\
Mathematics Education & Science Education \\
Arts and Crafts Education & Physics Education \\
Primary School Education & Japanese Language Teaching \\
History Education & Music Education \\
Turkish Language Teaching & Early Childhood Education \\
& Education of Turkish & Special Education \\
& Social Science Education \\
\hline
\end{tabular}

Instructional Technologies course is compulsory in all programs. Whereas the credit of the course whose 2 hours are theoretical is 2, ECTS is determined as 3 (YÖK, 2018b). Accordingly, no time is defined to the course for practice. As shown in Table 1, the semester in which the course is provided to students varies according to the departments. Besides, most of the undergraduate programs teach the course in the second academic year. Only the department of Psychological Counseling and Guidance (PCG) offers the Instructional Technologies course in the second semester. In a study that directly covered the course in the context of the literature, the necessity and content of the course was asked to the instructors (Illic, 2019). In other studies, the effect of the lesson was examined in a more indirect way and the benefit of the spatial thinking skill of Geography Teaching students in teaching was examined (Şanl1, 2019; Şanlı \& Jo, 2020).

\subsection{Amendments Carried Out in Teacher Training Undergraduate Program and} Purpose of the Study

That the Computer I and Computer II courses were removed and replaced by Information Technologies and Instructional Technologies courses as of the 2018-2019 academic year was defined in the regulations section about the general culture courses of the teacher competencies undergraduate programs file through the statements as follows (YÖK, 2018a):

\section{"Computer I and Computer II courses have been removed from the programs, and "Information Technologies" course including current technologies and "Instructional Technologies" course including technologies related to education and instruction have been added instead of these courses."}

According to the reason mentioned above, Computer I course was replaced by Information Technologies course, and Computer II course was replaced by Instructional Technologies course. However, as seen in Table 2, considering the credit status of Computer I and Computer II courses, it can be stated that both courses in the new curriculum are left behind in this context. In addition to this, the abolition of the ITMD course and the replacement of it with the Instructional Technologies course are stated in the regulations section related to Professional Teaching Knowledge courses as follows (YÖK, 2018a):

"Since Instructional Technologies and Material Development course has always been a subject of controversy between the departments due to its scope, it has been removed, and the content has been updated, and a course called "Instructional Technologies" has taken place in the programs." 
Table 2. Credit and Hour Status of Computer II, ITMD, and Instructional Technologies Courses

\begin{tabular}{llll}
\hline Course & Theoretical & Practice & Length \\
\hline Computer II & 2 & 2 & 4 \\
ITMT & 2 & 2 & 4 \\
Instructional Technologies & 2 & - & 2 \\
\hline
\end{tabular}

It was understood that the courses mentioned in the previous curriculum respectively took place in the first and second semesters in all curricula and that only the Information Technologies course among the courses provided in the new curriculum was in the first semester. As indicated in Table 1, Instructional Technologies course takes place in different semesters. It can be emphasized that even this situation proves that the curriculum does not show consistency in terms of the distribution of courses. On the other hand, the following statements are included in the principles section of undergraduate programs in order to reorganize this decrease in course time according to the wishes (YÖK, 2018a):

"In addition to the elective courses included in the curricula, maximum 6 courses can be added into Professional Knowledge (PK) and Field Education (FE) elective course pool by making justification and credit definitions in line with the interests, wishes, and needs of the students, proposing to YÖK by the last day of March, and getting the approval of YÖK. The elective courses to be added into the Field Education (FE) elective course pool must be directed towards the teaching of the subject area. There is no restriction for the courses to be added into General Culture (GC) elective courses. There is no need for YÖK approval in adding General Culture (GC) elective courses."

As comprehended from the statements given above, it is possible to provide elective courses so as to eliminate the shortcomings of the courses in terms of quantity and quality. However, how this opportunity will be taken in practice will be seen in time.

In the related literature, there are several studies on the benefits of instructional technologies and their positive effects on the learning environment (Abbitt, 2011; Haseski, 2019; Nicholl, Flutter, Hosking \& Clarkson, 2013; Wang, Shannon \& Ross, 2013). Instructional Technologies course has an important role in this context. In addition, the situation of this course, for which two different courses are removed and the course hours are shortened, is also a matter of curiosity. However, studies focusing on the course (Illic, 2019) or indirectly investigating its effect are not sufficient in the literature (Şanl1, 2019; Sanlı \& Jo, 2020). In this regard, the purpose of this study is to examine the opinions of pre-service teachers, one of the important stakeholders of the curriculum, about the Instructional Technologies course. In this way, it is thought to have knowledge about the reflections of the innovations made in the curriculum.

\section{METHOD}

\subsection{Research Model}

The study was carried out in the context of descriptive qualitative research design. The opinions of the participants were obtained in written format through the form generated by the researchers. Content analysis method was implemented to analyze the opinions. This method was preferred since it is effective in enabling to compare, classify, and relate the data (Fraenkel \& Wallen, 2000). 


\subsection{Participants}

The participants of the study consist of 101 pre-service teachers enrolling in the Department of PCG at Pamukkale University Faculty of Education in the 2018-2019 academic year. $73.3 \%$ of the study group were female. The distribution of participants according to age is presented in Table 3. According to this, although the ages of pre-service teachers vary from 18 to 29 , the average age is 19.46 . It can be stated that this low average is due to the fact that most of the participants start their undergraduate life immediately after completing their secondary education processes.

Table 3. Distribution of the Participants According to Age Levels

\begin{tabular}{lll}
\hline Age & $F$ & $\%$ \\
\hline 18 & 21 & 20.79 \\
19 & 40 & 39.60 \\
20 & 31 & 30.69 \\
21 & 6 & 5.94 \\
22 and over & 3 & 2.97 \\
Total & 101 & 100 \\
\hline
\end{tabular}

Criterion sampling, one of the purposeful sampling methods, was implemented to determine the study group of the research. The criterion sampling model is used under the conditions in which situations that are thought to contain rich information need to be examined in detail (Patton, 1987). Criterion sampling method is preferred when all cases formed by researchers or including the predetermined criteria are to be studied (Yıldırım \& Şimşek, 2011). In this context, starting education in the PCG Department of Pamukkale University Faculty of Education in the 2018-2019 academic year, enrollment in Instructional Technologies course, and being volunteer within the scope of participation in the study were determined as the criteria. The fact that the Instructional Technologies course was only in one department during the research period was effective in choosing to be enrolled in the abovementioned department and course. The study was completed with 101 students participating in the course on the days and hours of data collection among 110 pre-service teachers who met the first two conditions. All of these students were volunteer to participate in the study.

\subsection{Data Collection Tool}

The Instructional Technologies Beginning of Semester Form (ITBSF) and Instructional Technologies End of Semester Form (ITESF) were generated by the researcher in order to determine the opinions of pre-service teachers about Instructional Technologies course within the scope of the study. These forms, in which the opinions of the students are intended to be taken in written format, were processed by taking the opinions of 5 field experts of Computer Education and Instructional Technology (CEIT), 1 language specialist, and 1 assessment and evaluation specialist, and the final forms were generated after being tested through pilot study. Gender and age information were obtained through 2 demographic questions. In addition, there are 1 Yes/No question and 3 open-ended questions in ITBSF. The questions included in ITBSF are listed below:

- Do you have any information about the content of the Instructional Technologies course you will take during this academic semester? If your answer is "Yes", please write down what you know about the content.

- Did you know that this course was provided in the previous curriculum as Instructional Technologies and Material Design?

- What can you say about the necessity of Instructional Technologies course?

- What are your expectations from Instructional Technologies course? 
On the other hand, all the questions in ITESF are prepared as open-ended questions. These questions are as follows:

- What can you say about the necessity of Instructional Technologies course?

- What can you say about the content of the Instructional Technologies course in terms of satisfying your expectations at the beginning of the semester?

- If the Instructional Technologies course has contributed to you, what are these?

- What can you say about the effects of the Instructional Technologies course in preparing you for your profession?

- If yes, what can you say about the weaknesses of the Instructional Technologies course?

\subsection{Collection of Data}

Data collection process started on February 12, 2019 and finished on May 21, 2019. The process was carried out in the computer laboratories of Pamukkale University, Faculty of Education, and Department of CEIT. Data collection was started on February 12, 2019 and February 14, 2019 through the ITBSF. Data collection on two different dates was caused by the fact that the PCG section consisted of 2 branches. The researcher, who was also the lecturer at the same time, asked the students for their opinions without giving any information about himself or the course. In this way, it was tried to prevent the situations that could be affected by the bias of the students. The last two sessions were held on May 16, 2019 and May 21, 2019, which were the last course days of the relevant branches. In order to prevent the bias of the participants about the study, the grade entry was made for the course after these dates by the instructor. In all 4 sessions, the pre-service teachers satisfying the relevant criteria were included in the study group. The researcher took part in all sessions to help the students answer questions individually. However, the behaviors that would guide or judge them were avoided. In addition, precautions were taken in the computer laboratory against environmental factors that disrupt the peace of the process and interrupt it. Furthermore, at the beginning of the sessions, such information as the purpose of the study, the rights of the participants, and data privacy were presented in verbal and written format to the study group. In this way, it was tried to increase the readiness of the pre-service teachers for the research and to enable them to give their answers freely.

\subsection{Data Analysis}

Statistical program was conducted for the analysis of the data. This program was used for the demographic information and Yes/No questions in the ITBSF and ITESF. Descriptive statistics of the participants were calculated through the statistical program as well. Descriptive statistics were implemented since they provide such opportunities as classifying and summarizing data in research (Lomax \& Hahs Vaughn, 2012). On the other hand, MAXQDA qualitative data analysis program was processed for the analysis of open-ended questions. The data collected from these questions were analyzed by the expert researcher through the content analysis, and related codes and themes were generated. In addition to this, open-ended questions were analyzed by another expert with a $\mathrm{PhD}$ in Computer Education and Instructional Technology. Cohen's Kappa statistic was used to calculate the reliability between these coders. This value was found as $\kappa=.90$ for the ITBSF and $\kappa=.902$ for the ITESF. In this context, it can be stated that the concordance between coders is high (Landis \& Koch, 1977).

\subsection{Trustworthiness}

Various steps were followed to ensure trustworthiness in the study. In order to collect indepth data, a long-term interaction with the students was provided throughout the term. In addition to these, direct quotations and examples from participants' expressions were given to ensure the transferability of the study. Cohen's Kappa values were calculated for the internal validity values of the data obtained from the ITBSF and ITESF data collection tools. 


\subsection{Limitations}

The present study has several limitations. Qualitative research design was used in this study. In addition, due to the use of criterion sampling, people who met the limiting criteria could be selected for the study group. Another limitation is the data collection tools used in the study. The content of the Instructional Technologies course, determined by YÖK and applied by the researcher, is the last limitation.

\section{FINDINGS}

For the purpose of the study, the data obtained within the scope of the questions in the ITBSF and ITESF were classified under several headings. The related headings are presented in this section.

\subsection{Findings Related to Having Knowledge about the Content of the Course}

Most of the participants $(f=98)$ mentioned that they did not have any knowledge about the content of Instructional Technologies course. In this context, it was observed that the students, who expressed that they had knowledge, gave such answers as "setting up an office program" and "using PowerPoint program". It was seen that only 1 participant provided qualified knowledge about the content of the course. The student expressed his/her thoughts about the course as follows:

"I think it's about the technological materials used in education." [P26]

It can be stated that this is due to the low level of interest and readiness of the students to the course.

\subsection{Findings Related to the Status of the Course in the Previous Curriculum}

92.9\% of the participants mentioned that they did not know that Instructional Technologies was provided as ITMD course in the previous curriculum. This may be due to the fact that the students have just started their life in the university. In addition to this, the students were not informed about any changes in the curriculum of the courses they have taken in the first semester, and thus, this situation may be effective.

\subsection{Findings Related to the Necessity of the Course}

Data related to the necessity of the Instructional Technologies course were collected from the participants in both ITBSF and ITESF. The tables containing the themes and codes obtained as a result of these data are presented as follows:

Table 4. Themes and Codes Related to the Necessity of the Course at the Beginning of the Semester

\begin{tabular}{|c|c|c|c|}
\hline Themes & Codes & $f$ & Statements of Participants \\
\hline \multirow[t]{2}{*}{ Necessary } & & 82 & \\
\hline & $\begin{array}{l}\text { Necessary to use } \\
\text { ICT better }\end{array}$ & 49 & $\begin{array}{l}\text { "Computer and internet, which are among } \\
\text { the requirements of our age, are also very } \\
\text { helpful for us in instructional programs. } \\
\text { Therefore, it is almost imperative that we } \\
\text { have sufficient knowledge about them. I } \\
\text { find the instructional technologies course } \\
\text { quite necessary." [P62] }\end{array}$ \\
\hline
\end{tabular}




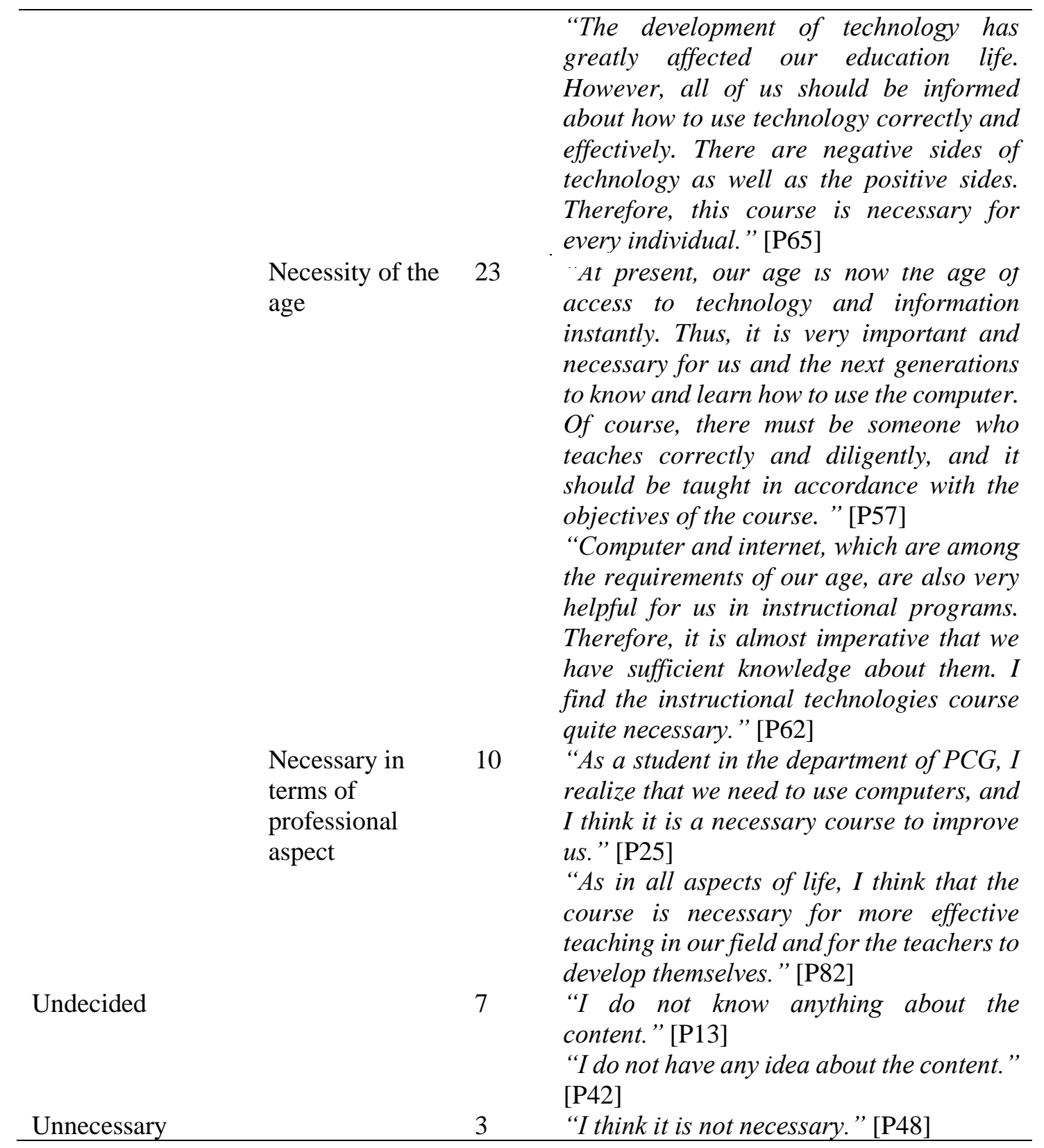

As can be seen from the results in Table 4, most of the participants think that Instructional Technologies course is necessary. Pre-service teachers respectively mention that the course is necessary in order to use ICT well, to keep up with the age and professional gain. Seven of the participants expressed that they were undecided about the necessity of the course. However, when the statements of the pre-service teachers were examined, it was observed that this situation stems from insufficient knowledge about the content. On the other hand, three students stated that the course was not necessary.

Table 5. Themes and Codes Related to the Necessity of the Course at the end of the Semester

\begin{tabular}{llll}
\hline Themes & Codes & $f$ & Statements of Participants \\
\hline Necessary & 99 & \\
$\begin{array}{l}\text { Necessary to be } \\
\text { able to use ICT } \\
\text { well }\end{array}$ & 59 & $\begin{array}{l}\text { "In my opinion, it is a necessary } \\
\text { course for me in terms of using } \\
\text { technology and teaching its effective } \\
\text { use in the course." [P3] }\end{array}$ \\
\hline
\end{tabular}




\begin{tabular}{|c|c|c|c|}
\hline & $\begin{array}{l}\text { Necessity of the } \\
\text { age }\end{array}$ & 21 & $\begin{array}{l}\text { "It provides the most accurate } \\
\text { representation of the place and use } \\
\text { of technology in teaching." [P7] } \\
\text { "It is one of the most important } \\
\text { lessons for me because the 21st } \\
\text { century is the technology age, and } \\
\text { we have to keep up with it. As you } \\
\text { know, it is very important to use } \\
\text { technology to lecture the course } \\
\text { best. Therefore, it is very } \\
\text { necessary." [P38] } \\
\text { "It is absolutely necessary in the } \\
\text { developing conditions of the } 21 \text { st } \\
\text { century. It makes us more active and } \\
\text { knowledgeable in the presentations } \\
\text { made in places like schools, work, } \\
\text { institutions etc." [P60] }\end{array}$ \\
\hline & $\begin{array}{l}\text { Necessary in terms } \\
\text { of professional } \\
\text { aspect }\end{array}$ & 13 & $\begin{array}{l}\text { "I think that instructional } \\
\text { technologies course is a necessary } \\
\text { course so as to learn the technology } \\
\text { at present, and it provides } \\
\text { professional benefit." [P44] } \\
\text { "I believe that I can be more } \\
\text { productive in the experiences in my } \\
\text { professional life thanks to teaching } \\
\text { technologies." [P77] }\end{array}$ \\
\hline & $\begin{array}{l}\text { Necessary to } \\
\text { facilitate life }\end{array}$ & 6 & $\begin{array}{l}\text { "Makes our work in daily life } \\
\text { easier" [P9] } \\
\text { "It enables us to learn about } \\
\text { computer and technology and to use } \\
\text { technology in daily life." [P49] }\end{array}$ \\
\hline Unnecessary & & 2 & $\begin{array}{l}\text { "I don't think it's necessary to take } \\
\text { this course." [P90] }\end{array}$ \\
\hline
\end{tabular}

According to Table 5, it was determined that most of the participants consider the Instructional Technologies course as necessary. It can be stated that the increase in this number compared to the beginning of the semester indicates that the students believe in the importance of the course more. Similar to the first situation, the participants stated that they consider the course as necessary for good use of ICT, keeping up with the age and professional gain. Moreover, 6 students emphasized the importance of the course in terms of facilitating life. When the responses of the participants, who considered the necessity of the course as the necessity of the age, are examined, it is observed that the course is emphasized in its place in the 21 st century conditions. It can be said that this situation is caused by the change of the perspective of the students who have seen the related courses during a semester. On the other hand, only 2 participants stated that they did not consider the course as necessary. Considering that this number was 3 at the beginning of the semester and the number of those who are undecided about considering the course as necessary was 7 , it can be concluded that the attitude towards the necessity of the course has changed positively.

\subsection{Findings Related to the Expectations from the Course}

Data were collected both at the beginning and at the end of the semester in order to determine the expectations of the participants from the course. The themes formed as a result of the data collected through ITBSF at the beginning of the semester are presented as follows: 
Table 6. Themes Related to the Expectations from the Course

\begin{tabular}{|c|c|c|}
\hline Themes & $F$ & Statements of Participants \\
\hline Learning ICT & 60 & $\begin{array}{l}\text { "Using technology with } 100 \% \text { efficiency in the } \\
\text { name of education and training." [P16] } \\
\text { "To have more ideas about technology and its } \\
\text { use in teaching." [P26] } \\
\text { "I expect to use technology for better and } \\
\text { necessary things, and This course makes it (in } \\
\text { terms of courses) easier for us." [P65] }\end{array}$ \\
\hline $\begin{array}{l}\text { Professional } \\
\text { development }\end{array}$ & 14 & $\begin{array}{l}\text { "As a pre-service teacher of the future, I expect } \\
\text { that it will provide me with sufficient information } \\
\text { and equipment while teaching at the institutions } \\
\text { I will be active in." [P62] } \\
\text { "I would like to learn the information that will } \\
\text { help me in my professional life." [P75] }\end{array}$ \\
\hline No expectation & 6 & $\begin{array}{l}\text { "I have no expectations." [P48] } \\
\text { "NO EXPECTATION" [P80] }\end{array}$ \\
\hline Facilitating life & 5 & $\begin{array}{l}\text { "I want it to provide something to make my life } \\
\text { easier." [P3] } \\
\text { "Learning practical programs that will facilitate } \\
\text { my work in my professional and daily life." [P6] }\end{array}$ \\
\hline No idea & 3 & $\begin{array}{l}\text { "I do not know enough about this course. I find } \\
\text { it appropriate to progress in this way as shown } \\
\text { by our teacher." [P74] }\end{array}$ \\
\hline
\end{tabular}

As can be seen in Table 6, most of the participants have the expectation of learning ICT from the course. This may be due to the name of the course. This expectation is followed by the professional development and facilitating life. On the other hand, 9 students demonstrated that they do not have any knowledge about this subject or do not have any expectations. As indicated by P74, this situation may have been influenced by the insufficient knowledge of pre-service teachers about the course content.

At the end of the semester, data were collected through ITESF so as to obtain information on the status of satisfying the expectations by the course. The themes and codes formed according to this are shown in Table 7:

Table 7. Themes and Codes Related to the Status of Satisfying the Expectations by the Course

\begin{tabular}{|c|c|c|c|}
\hline Themes & Codes & $f$ & Statements of Participants \\
\hline \multirow{2}{*}{$\begin{array}{l}\text { It satisfied } \\
\text { expectation }\end{array}$} & & 94 & \\
\hline & $\begin{array}{l}\text { My expectation was } \\
\text { generally satisfied }\end{array}$ & 83 & $\begin{array}{l}\text { "It is satisfying. I think I've } \\
\text { learned so much more than I need } \\
\text { to learn." [P5] } \\
\text { "I thought we would only do } \\
\text { practice in the course content, but } \\
\text { it was also nice to have a verbal } \\
\text { transfer besides the practice. We } \\
\text { looked at the past as well as our } \\
\text { current technology. We have } \\
\text { learned about most terms, } \\
\text { practice, and programs." [P15] }\end{array}$ \\
\hline
\end{tabular}




\begin{tabular}{|c|c|c|c|}
\hline & $\begin{array}{l}\text { My expectation was } \\
\text { satisfied in the } \\
\text { context of learning } \\
\text { ICT }\end{array}$ & 11 & $\begin{array}{l}\text { "It satisfied my expectations. I } \\
\text { have learned more about } \\
\text { technology." [P43] } \\
\text { "It was more productive than the } \\
\text { computer course that we took in } \\
\text { the first semester. We have } \\
\text { learned the basic things that we } \\
\text { need to learn, and whereas we } \\
\text { didn't know anything about the } \\
\text { computer in the past, I have the } \\
\text { desire to improve and apply what } \\
\text { I have learned right now." [P59] }\end{array}$ \\
\hline $\begin{array}{l}\text { It slightly satisfied } \\
\text { my expectation }\end{array}$ & & 5 & $\begin{array}{l}\text { "To me, it has the lack of } \\
\text { something. I think that the topics } \\
\text { were processed superficially, and } \\
\text { this course should be studied for } \\
\text { two semesters." [P3] } \\
\text { "No matter how good I was told, } \\
\text { it was a difficult lesson because I }\end{array}$ \\
\hline & & & $\begin{array}{l}\text { am bad at computers or } \\
\text { technological tools. I thought it } \\
\text { was an easier lesson." [P82] }\end{array}$ \\
\hline No expectation & & 2 & $\begin{array}{l}\text { "I do not have any expectation" } \\
{[\mathrm{P} 9] \text { and }[\mathrm{P} 10]}\end{array}$ \\
\hline
\end{tabular}

Table 7 indicates that the expectations of the participants from the Instructional Technologies course are generally satisfied. Accordingly, whereas a large part of the pre-service teachers stated that the courses satisfied their expectations, some of them mentioned that the course satisfied their expectations in terms of learning ICT. This is consistent with the results presented in Table 6. Five of the students stated that the courses partially satisfied their expectations from the course. When the responses of these participants are examined, it can be said that this is due to the students themselves. On the other hand, two pre-service teachers emphasized at the end of the semester that they did not have expectations from the course. The fact that this number, which was 9 at the beginning of the semester, dropped to 2 could be considered as relatively positive.

\subsection{Findings Related to the Contributions of the Course}

Data were collected through ITESF so as to determine the contribution of the Instructional Technologies course to the participants. The themes formed according to this are presented in Table 8:

Table 8. Themes Related to the Contributions of the Course

\begin{tabular}{lll}
\hline Themes & $F$ & Statements of Participants \\
\hline Learning to use ICT & 93 & "It allowed me to understand the information I \\
& need about the programs I will use in the future. \\
& It taught more practical procedures." [P63] \\
& "It enabled me to use technology more useful." \\
& [P86] \\
& "We have learned how to consciously use \\
& technology." [P100] \\
& "I have learned about important applications \\
& that we should use in our professional life. \\
Professional & Apart from that, I learned about the evolution \\
development &
\end{tabular}




\begin{tabular}{|c|c|c|}
\hline & & $\begin{array}{l}\text { of literacy and technology from the past to the } \\
\text { present." [P59] }\end{array}$ \\
\hline & & $\begin{array}{l}\text { "If I'm going to be a school counselor, my } \\
\text { presentations will be more interesting." [P77] }\end{array}$ \\
\hline No contribution & 2 & $\begin{array}{l}\text { "I saw the elements I had already learned. This } \\
\text { course didn't contributed to me." [P18] } \\
\text { "I have not realized that it contributes to me } \\
\text { right now." [P57] }\end{array}$ \\
\hline $\begin{array}{l}\text { Increasing interest in the } \\
\text { course }\end{array}$ & 1 & $\begin{array}{l}\text { "My interest in the course has increased." } \\
{[\mathrm{P} 40]}\end{array}$ \\
\hline
\end{tabular}

As concluded in Table 8, most of the pre-service teachers demonstrated that they benefited from the Instructional Technologies course in terms of using ICT. This finding is consistent with the findings in Tables 4, 5, 6, and 7. Five participants thought that the course would help them in their profession. One of the students stated that their interest in the course increased. On the other hand, two participants stated that the course did not contribute to them. When the statements of these pre-service teachers are examined, it can be said that they think this because they do not make enough contribution because they are above a certain level.

\subsection{Findings Related to the Effects of the Course in Terms of Preparing for the Profession}

Data were collected through ITESF in order to determine the effects of the Instructional Technologies course in terms of preparation for the profession. According to this, the majority of the participants $(f=97)$ mentioned that the course contributed to them in terms of teaching effective use of ICT. The students expressed his/her thoughts about the course as follows:

"I thought we would only practice in the content, but it was nice to have a verbal transmission as well as the application. We have looked at the past as well as today's technology. We learned about many terms, applications and programs." [P27]

"I learned about important applications that we should use in our professional life. Apart from that, I learned about literacy and the evolution of technology from past to present." [P53]

The remaining four said that they were undecided.

\subsection{Findings Related to the Weaknesses of the Course}

Data were collected from the participants through ITESF in order to determine the missing aspects of the Instructional Technologies course. The themes, codes and participant statements that emerge in this context are as follows:

Table 9. Themes and Codes Related to the Weaknesses of the Course

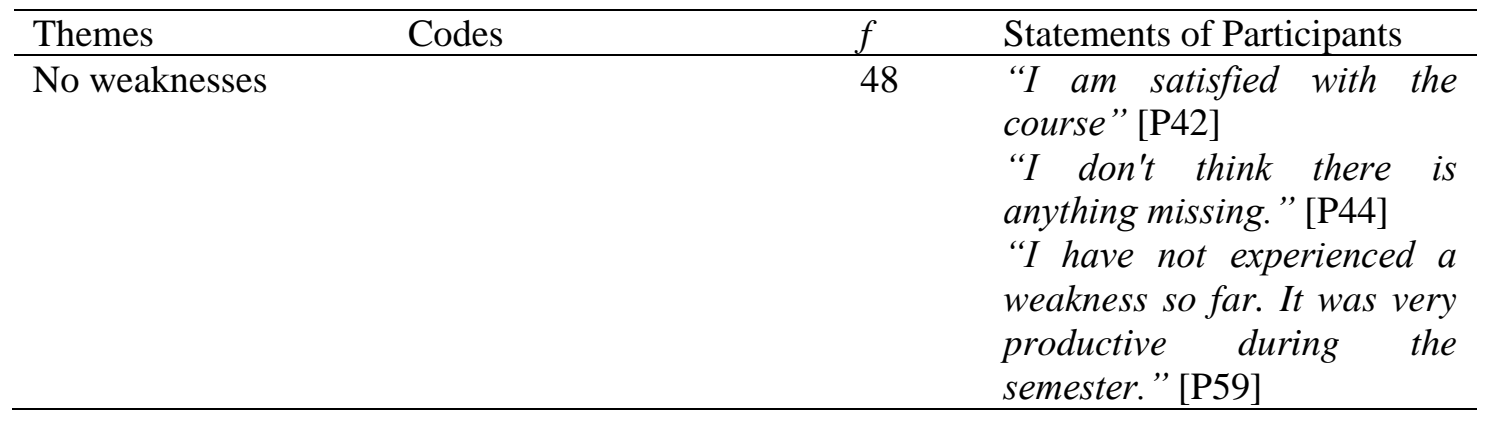




\begin{tabular}{|c|c|c|c|}
\hline \multirow[t]{6}{*}{ Slightly Weak } & \multicolumn{3}{|c|}{36} \\
\hline & $\begin{array}{l}\text { The content is } \\
\text { predominantly theoretical }\end{array}$ & 16 & $\begin{array}{l}\text { "It is annoying that some } \\
\text { subjects are too verbal." } \\
{[\mathrm{P} 33]} \\
\text { "No, I think the practice is } \\
\text { more useful than theoretical } \\
\text { knowledge." [P97] }\end{array}$ \\
\hline & Insufficient course hours & 10 & $\begin{array}{l}\text { "As a country, this course is } \\
\text { not given enough } \\
\text { importance." [P64] } \\
\text { "Since it is a wide subject, it } \\
\text { is difficult to give all the } \\
\text { information." }[\mathrm{P} 100]\end{array}$ \\
\hline & High class population & 8 & $\begin{array}{l}\text { "The number of students is } \\
\text { too high. I cannot satisfy too } \\
\text { much individually." [P21] } \\
\text { "First of all, the class is very } \\
\text { crowded. I cannot sometimes } \\
\text { find a computer." [P38] }\end{array}$ \\
\hline & Causing health problems & 1 & $\begin{array}{l}\text { "My eyes get very tired since } \\
\text { the course is based on } \\
\text { computer." }[\mathrm{P} 28]\end{array}$ \\
\hline & $\begin{array}{l}\text { Inability to learn to use } \\
\text { ICT instruments actively }\end{array}$ & 1 & $\begin{array}{l}\text { "I didn't learn to use } \\
\text { projection and other } \\
\text { electronic devices actively." } \\
{[\mathrm{P} 4]}\end{array}$ \\
\hline
\end{tabular}

According to the answers received at the end of the semester that are shown in Table 9, most of the pre-service teachers stated that there is no weakness of Instructional Technologies course. In addition to this, it was understood that these participants considered the course as productive. On the other hand, a total of 36 pre-service teachers stated that there were deficiencies in the course for several reasons. These weaknesses are related to theoreticallyweighted content, insufficiency of class hours, high class population, health problems, and not being able to use ICT instruments actively. Because of the nature of the course, the content is theoretically weighted, and the course hours can be considered as insufficient. The content of the course consists of verbal subjects, and 2 course hours are theoretical. Besides, high class population can be seen as an administrative problem. According to this, it can be seen as justification that the management decided that 110 students have to be taught within only 2 branches. One of the students stated that their eyes were tired. The occurrence of such a situation in the course, which lasts 2 hours in total and can only be practiced in a certain part of this period, may also be related to the personal problems of this student. On the other hand, 1 participant stated that he/she could not learn to use projection and other electronic devices actively. Although it cannot be understood what other electronic tools are meant, the fact that projection is actively used in the course and the reference to this tool while explaining the subject of instructional technology tools make the statement of this student look suspiciously.

\section{DISCUSSION, CONCLUSION AND RECCOMMENDATIONS}

This research was carried out to determine the opinions of pre-service teachers about Instructional Technologies course. For the purposes mentioned, data were collected from 101 pre-service teachers studying in the department of PCG in Faculty of Education at Pamukkale University in Turkey. The findings are thought to be useful in terms of examining the status of 
Instructional Technologies course which is new in the curriculum. Since there was limited literature regarding the subject, the findings were discussed in the context of both these studies and Computer II and ITMD courses, which were included in the previous curriculum.

It was determined that the pre-service teachers did not have knowledge about the content of Instructional Technologies course. However, not only this course, but also all the courses of the curriculum are given publicly on the webpage of the institution (Information Package \& Course Catalog, 2019). In addition to this, although Information Technologies course provided in the first semester is not mentioned as a whole in the old curriculum as Computer I and II, it is the beginning of Instructional Technologies course in terms of content (YÖK, 2018a). In this course, the necessary information are expected to be provided to the students by the instructor. On the other hand, the lack of knowledge about the content may be due to their lack of interest in the course. Similarly, it was observed that the students were also uninformed about the previous status of the course in the curriculum. It can be said that this is due to the fact that the students are in their first year of undergraduate education. In addition to this, it is thought that the pre-service teachers were not informed about the change carried out in the courses of the curriculum of the Faculties of Education they took in the first semester. However, it is observed that the students take such basic courses as Introduction to Education and Educational Sociology in the first semester. When the purposes and contents of these courses are examined (YÖK, 2018 b), it is expected that this situation should have been briefly explained to the pre-service teachers.

The expectations of the pre-service teachers from the course were dominantly determined as learning ICT. This is thought to be due to the fact that the name of the course is Instructional Technologies. This finding is in line with the literature (Şanlı \& Jo, 2020). This expectation is followed by professional development. These findings confirm the studies in the literature as well (Şanll, 2019; Sanlı \& Jo, 2020). In addition, the findings coincide with the literature dealing with other courses (Elald1, 2018; Kinay, Ömer, Bağçeci \& Çetin, 2015; Özen, 2013; Uzunöz et al., 2017). At the end of the semester, it was determined that the expectations of the students from the course were mostly satisfied. The fact that the expectations of the pre-service teachers at the end of the semester were more positive than the beginning of the semester supports this finding. Furthermore, it can be stated that these findings coincide with the positive attitude findings of Computer II course (Birişçi \& Karal, 2011; Çuhadar, 2010; Çukurbaş1 \& Kıyıc1, 2018a, 2018b; Haseski \& İlic, 2020; Mihc1 Türker \& Pala, 2018).

It was determined that most of the pre-service teachers considered the Instructional Technologies course as necessary. This finding is similar to the findings of the study, which directly deals with the course in the literature (Ilic, 2019). In addition, the opinions of the participants in this context at the beginning of the semester changed in favor of the necessity of the course at the end of the semester. This situation overlaps with the literature stating that Computer II and ITMD courses are also necessary (Haseski \& İlic, 2020; Karataş \& Yapıc1, 2006; Uzunöz et al., 2017; Yazar, 2015). Furthermore, the course was found to be necessary for the effective use of ICT and adaptation to the age. This situation is in line with the course content which includes such topics as instructional technologies as instruments and materials, design of instructional materials, designing thematic instructional materials (YÖK, 2018b). Since our age is accepted as the age of technology, this finding is expected.

The contribution of Instructional Technologies course to the pre-service teachers was found to be positive. The contributions of the course are asked in general terms, and professional contributions are directed to the students as questions in order to determine this contribution. Nevertheless, it was concluded that the answers to both questions were clustered around using ICT effectively. When the content of the course is examined, it is seen that this result is expected (YÖK, 2018b). In addition, the finding is similar to the findings of Sanlı and Jo (2020). On the other hand, there were students who stated that Instructional Technologies course contributed to 
them in professional context. This finding is consistent with the literature as well (Özen, 2013; Uzunöz et al., 2017).

It was also concluded that most of the pre-service teachers considered the Instructional Technologies course as almost complete. This finding coincides with the literature (Çuhadar, 2010; Çukurbaş1 \& Kıyıcı, 2018a, 2018b; Elaldı, 2018; Kinay et al., 2015; Uzunöz et al., 2017). On the other hand, some deficiencies of the course in several contexts are also mentioned. For instance, the content was found to be predominantly theoretical. It is seen in the new curriculum that this is due to the content of the course (YÖK, 2018b). However, learners should be provided with an appropriate time and application opportunity for an effective learning (Burden \& Byrd, 2018; Senemoğlu, 2018). Besides, this finding does not coincide with the necessity of both theoretical and practical courses on technology integration (Elald1, 2018). The theoretical situation of the course is also reflected in the content, and the pre-service teachers are disturbed by this situation. In addition to this, it was observed that the course hours were low. As mentioned before, the course was reduced to 2 hours, which led to the finding that it was deemed inadequate by the pre-service teachers. This finding is parallel with the findings of the only study in the literature that focuses on the course (Illic, 2019). The high class population is another problem that emerges as a problem in the administrative context. In order to overcome this situation, it may be useful to enable the course to be processed with more branches and fewer students.

To sum up, Instructional Technologies course is a course which is considered necessary by the pre-service teachers despite its theoretical structure and insufficient teaching hours, and which is thought to be useful for them in terms of learning ICT. In addition to this, it is a course based on technology integration, but it has some deficiencies since it has just been put in practice in the curriculum. It has been observed that the course should be considered within the framework of the delegation decision taken by YÖK (2020) to Education Faculties. In addition to this, considering the importance of effective use of instructional technologies in the improvement of the education system (Çağıltay, Çakıroğlu, Çağıltay \& Çakıroğlu, 2001),

- the reasons for the change in the opinions of the pre-service teachers can be examined.

- the effect of the course on ICT skills of the pre-service teachers can be investigated.

- some other researches can be carried out with pre-service teachers studying in different faculties of education and at different class levels of other departments.

- similar studies can conducted within the scope of Information Technologies course in the new curriculum similar to Instructional Technologies course.

\section{REFERENCES}

Abbitt, J. T. (2011). An investigation of the relationship between self-efficacy beliefs about technology integration and technological pedagogical content knowledge (tpack) among preservice teachers. Journal of Digital Learning in Teacher Education, 27(4), 134-143.

Acer, D. (2011). A study on the viewpoints of preschool teacher candidates on Design of Instructional Materials course. Elementary Education Online, 10(2), 421-429.

Birişçi, S., \& Karal, H. (2011). Effect of collaborative studies on prospective teachers' creative thinking skills while designing computer based material. Ahi Evran University Faculty of Education Journal, 12(2), 203-219.

Burden, P. R., \& Byrd, D. M. (2018). Methods for effective teaching: Meeting the needs of all students ( $8^{\text {th }}$ Press). NY: Pearson Education. 
Çağıltay, K., Çakıroğlu, J., Çağıltay, N., \& Çakıroğlu, E. (2001). Teachers' perspectives about the use of computers in education. Hacettepe University Journal of Education, 21, 19-28.

Çuhadar, C. (2010). Views of foreign language teacher candidates about blog use in Computer-II course. Trakya University Journal of Social Sciences, 12(1), 147-164.

Çukurbaşı, B., \& Kıyıcı, M. (2018a). An analysis on the change in preferences of preservice teachers towards use of the internet technologies in teaching. Kastamonu Education Journal, 26(3), 765-776.

Çukurbaşı, B., \& Kıyıcı, M. (2018b). A review on opinions of preservice teachers on the electronic portfolio: The example of Weebly. Inönü University Journal of the Faculty of Education, 19(1), 1-14.

Elald1, S. (2018). Evaluation of material development and presentation process within the scope of Instructional Technologies and Material Design course. Cumhuriyet International Journal of Education, 7(4), 551-570. http://dx.doi.org/10.30703/cije.468442

Engin, A. O., Tösten, R., \& Kaya, M. D. (2010). Computer based instruction. Kafkas University Journal of Social Sciences, 5(1), 69-80.

Fraenkel, J. R., \& Wallen, N. (2000). How to design and evaluate research in education (4th Ed.). New York: McGraw-Hill.

Gündüz, Ş., \& Odabaşı, F. (2004). The importance of Instructional Technologies and Material Development course at pre-service teacher education in information age. The Turkish Online Journal of Educational Technology, 3(1), 43-48.

Haseski, H. İ. (2019). Bilişim Teknolojileri dersi: Öğretmen adaylarının bakış açısından bir değerlendirme. Trakya Eğitim Dergisi, 9(4), 666-679.

Haseski, H. İ. \& İlic, U. (2020). The effect of Computer II course on the achievements of preservice teachers and their attitudes towards computer-assisted instruction. International Journal of Education Technology and Scientific Researches, 5(11), 1-34.

İlic, U. (2019). Ögrretim elemanları gözüyle Öğretim Teknolojileri dersi. Paper presented at the 1st International Beydağı Social and Humanities Congress, Malatya.

Information Package \& Course Catalogue (2019, January 4) Information package \& course catalogue. Retrieved from https://ebs.pau.edu.tr/BilgiGoster/Program.aspx?lng=2\&dzy $=3 \& \mathrm{br}=19 \& \mathrm{bl}=46 \& \mathrm{pr}=22 \& \mathrm{dm}=1 \& \mathrm{ps}=0$

Karataş, S., \& Yapıcı, M. (2006). The process and application samples of Teaching Technologies and Material Development. Afyon Kocatepe University Journal of Social Science, 8(2), 311-325.

Kinay, İ., Ömer, Ş., Bağçeci, B., \& Çetin, B. (2015). Examination of the attitudes of prospective teachers towards Instructional Technologies and Material Design (ITMD) course in terms of some variables. Dicle Üniversitesi, Ziya Gökalp Eğitim Fakültesi Dergisi, 25, 119-135.

Kirschner, P., Wubbels, T., \& Brekelmans, M. (2009). Benchmarks for teacher education programs in the pedagogical use of ICT. In J. Voogt \& G. Knezek (Ed.), International handbook of information technology in primary and secondary education (pp. 435-447). New York, NY: Springer.

Kolburan Geçer, A. (2010). Experience of technical teacher candidates towards Teaching Technologies and Material Development course. Van Yuzuncu Yil University Journal of Education, 7(2), 1-25.

Landis, J. R., \& Koch, G. G. (1977). The measurement of observer agreement for categorical data. Biometrics, 33, 159-174. 
Lomax, R. G., \& Hahs Vaughn, D. L. (2012). An introduction to statistical concepts (3rd Ed.). New York: Taylor and Francis Group.

Mihc1 Türker, P., \& Pala, F. K. (2018). Teacher candidate's opinions on presentation programs. Kastamonu Education Journal, 26(6), 1875-1885. doi:10.24106/kefdergi.2207

Nicholl, B., Flutter, J., Hosking, I., \& Clarkson, P. J. (2013). Joining up to DOTs: Authentic teaching and learning in design and technology education. Cambridge Journal of Education, 43 (4), 435-450.

Özen, R. (2013). Preservice teachers' training and technology use: A case study. International Journal of Human Sciences, 10(2), 147-162.

Patton, M. Q. (1987). How to use qualitative methods in evaluation. CA: Sage.

Saka, A. ve Saka, A. (2014). Öğretmen adaylarının Öğretim Teknolojileri ve Materyal Geliştirme dersinde mesleki becerilerini geliştirme düzeyi: Sakarya örneği. Sakarya University Journal of Education Faculty, O(10), 81-89.

Senemoğlu, N. (2018). Gelişim öğrenme ve öğretim: Kuramdan uygulamaya (25. Baskı). Ankara: Anı Yayıncilik.

Şanlı, C. (2019). Coğrafya ögretmen adaylarının mekânsal düsünme becerisine ilişkin görüşleri. Anadolu Kültürel Araştırmalar Dergisi (ANKAD), 3(3), 215-233. http://www.ankad.org/index.php/Ankad/article/view/59

Şanlı, C., \& Jo, I. (2020). Examining preservice geography teachers' dispositions to teach spatial thinking skills. International Journal of Eurasian Education and Culture, 11(5), 20692102.

Uzunöz, A., Aktepe, V. ve Gündüz, M. (2017). Öğretim Teknolojileri ve Materyal Tasarımı Dersinin, mesleki açıdan kazandırdıklarına ilişkin öğretmen adaylarının görüşleri: Nitel bir çalışma. Journal of Qualitative Research in Education, 5(3), 317-339.

Yaman, H. (2007). Türkçe öğretmeni adaylarının Öğretim Teknolojileri ve Materyal Geliştirme dersi bağlamında Türkçe öğretiminde teknoloji kullanımına ilişkin yeterlilik ve algıları. HAYEF Journal of Education, 7(1), 57-71.

Yazar, T. (2015). The relationship between preservice teachers' attitudes towards Instructional Technology and Material Design course, creativity perceptions and self-efficacy beliefs. International Journal of Curriculum and Instructional Studies, 5(9), 23-34.

Yelken, T. Y. (2009). The effects of materials development based on "creativity activities within a group" on teacher candidates' portfolios. Education and Science, 34(153). 83-98.

YÖK (2007). Öğretmen yetiştirme ve eğitim fakülteleri (1982-2007) (Öğretmenin üniversitede yetiştirilmesinin değerlendirilmesi). Ankara: Yükseköğretim Kurulu Yayını.

YÖK (2018a, March 5). Öğretmen yetiştirme lisans programlart. Retrieved from https://www.yok.gov.tr/Documents/Kurumsal/egitim_ogretim_dairesi/Yeni-Ogretmen-Ye tistirme-Lisans_Programlari/Rehberlik_ve_Psikolojik_Danismanlik_Lisans_Programi.pdf

YÖK (2018b, March 5). Rehberlik ve psikolojik danışmanlık lisans programı. Retrieved from https://www.yok.gov.tr/Documents/Kurumsal/egitim_ogretim_dairesi/Yeni-Ogretmen-Ye tistirme-Lisans-Programlari/AA_Sunus_\%20Onsoz_Uygulama_Yonergesi.pdf

YÖK (2020, August 31). Eğitim fakültelerine yetki devri. Retrieved from https://www.yok.gov.tr/Sayfalar/Haberler/2020/egitim-fak\%C3\%BCltelerineyetkidevri.as px

Yıldırım, A., \& Şimşek, H. (2011). Qualitative research methods in social sciences (8th Ed.). Ankara: Seçkin. 
Wang, C., Shannon, D. M., \& Ross, M. E. (2013). Students' characteristics, selfregulated learning, technology self-efficacy, and course outcomes in online learning. Distance Education, 34(3), 302-323.

\section{GENișLETILMIŞ ÖZ}

Teknolojinin hayatımız ile giderek iç içe geçtiği günümüzde bilgi ve iletişim teknolojilerine yönelik beceriler önem kazanmaktadır. $\mathrm{Bu}$ önem her alanda kendisini göstermektedir. Eğitim de bilgi ve iletişim teknolojilerinin önemi kapsamında öne çıkan alanlardan biridir. Söz konusu yetinin gelecek kuşaklara aktarılması için öğretmenler eğitim alanında anahtar konumda yer almaktadır. Ancak öncelikle bu kişilere bilgi ve iletişim teknolojileri becerilerinin kazandırılması gerekmektedir. Bu kapsamda öğretmen adaylarının bu becerilerini öğrenimleri sürecinde alacakları derslerde geliştirmeleri önemli görülmektedir. $\mathrm{Bu}$ nedenle söz konusu bağlamda yer alan dersler daha da önem göstermektedir. Öğretim Teknolojileri dersi yenilenen öğretim programında söz konusu bağlamda yer alan derslerden biridir. Bu dersin ise gerek kredi gerekse yerine getirildiği dersler bağlamında farklı durumları bulunmaktadır. Yeni öğretim programında Bilgisayar I ve Bilgisayar II derslerinin kaldırılıp yerlerine Bilişim Teknolojileri ve Öğretim Teknolojileri derslerinin getirildiği belirtilmektedir. Ancak Bilgisayar I ve Bilgisayar II derslerinin kredi durumları dikkate alındığında, yeni programda yer alan her iki dersin de bu bağlamda geride kaldığı söylenebilir. Buna ek olarak Öğretim Teknolojileri ve Materyal Geliştirme dersinin kaldırılıp, yerine Öğretim Teknolojileri dersinin getirildiği de belirtilen diğer bir noktadır. Önceki programda yer alan Bilgisayar I ve Bilgisayar II derslerinin tüm öğretim programlarında sırasıyla 1. ve 2. yarıyıllarda yer aldığ ancak yeni programda yer verilen derslerden yalnızca Bilişim Teknolojileri dersinin 1. yarıyılda olduğu belirlenmiştir. Öğretim Teknolojileri dersi ise çok farklı yarıyıllarda yer almaktadır. Bu durumun dahi öğretim programının derslerin dağılımı bağlamında tutarlılık göstermediğine kanıt oluşturduğu söylenebilir. Tüm bu durumlar Öğretim Teknolojileri dersinin durumunun incelenmesini değerli duruma getirmektedir. Alanyazında öğretim teknolojilerinin yararları ve öğrenme ortamı üzerine olan olumlu etkileri ile ilgili çeşitli çalışmalar bulunmaktadır. Ancak Öğretim Teknolojileri dersini odağına alan çalışmalar gerek nicelik gerek ise nitelik bağlamda düşük düzeydedir. Bu kapsamda çalışmanın amacı öğretim programının önemli paydaşlarından biri olan öğretmen adaylarının Öğretim Teknolojileri dersine yönelik görüşlerini incelemektir. $\mathrm{Bu}$ sayede öğretim programında yapılan yeniliğin uygulamaya yansımaları konusunda bilgi sahibi olunabileceği düşünülmektedir.

Çalışmada betimleyici nitel araştırma deseni kullanılmıştır. Bu yöntemin seçilmesinde verileri karşılaştırmaya, sınıflamaya ve birbirleriyle ilişkilendirmeye uygun olması etkili olmuştur. Araştırmanın katılımcılarını 2018-2019 Eğitim-Öğretim yılında Pamukkale Üniversitesi Eğitim Fakültesi'nin Rehberlik ve Psikolojik Danışmanlık Bölümü'ne kayıt yaptıran 101 öğretmen adayı oluşturmaktadır. Çalışma grubunun belirlenmesi için amaçlı örnekleme yöntemlerinden biri olan ölçüt örnekleme kullanılmıştır. Bu bağlamda araştırmada Pamukkale Üniversitesi Eğitim Fakültesi'nin Rehberlik ve Psikolojik Danışmanlık Bölümü'ne 2018-2019 Eğitim-Öğretim yılında öğrenime başlama, Öğretim Teknolojileri dersine kayıtlı olma ve çalışmaya katılım kapsamında gönüllü olma ölçütler olarak belirlenmiştir. Çalışma kapsamında Öğretim Teknolojileri dersine yönelik öğretmen adaylarının görüşlerini belirleyebilmek amacıyla araştırmacı tarafından Öğretim Teknolojileri Dönem Başı Formu ve Öğretim Teknolojileri Dönem Sonu Formu geliştirilmiştir. Söz konusu formlarda cinsiyet ve yaş bilgileri, 2 demografik soru ile elde edilmiştir. Bu araçlar veri toplama araçları olarak işe koşulmuştur. Araştırmanın veri toplama süreci 12 Şubat 2019 tarihinde başlamış ve 21 Mayıs 2019 tarihinde bitirilmiştir. Çalışmadan elde edilen verilerin analizi için istatistik ve nitel veri analizi programı kullanılmıştır. İstatistik programı öğretmen adaylarının betimsel özelliklerini belirlemede işe koşulmuştır. Nitel veri analizi programı ise diğer sorulardan gelen yanıtların 
içerik analizine tabi tutulması sürecinde kullanılmıştır. Çalışmada güvenilirliği sağlamak için çeşitli adımlar izlenmiştir. Katılımcılardan derinlemesine veri toplamak amacıyla, öğrencilerle uzun süreli etkileşim dönem boyunca sağlanmıştır. Bunlara ek olarak, çalışmanın aktarılabilirliğini sağlamak için doğrudan alıntılar ve katılımcıların ifadelerinden örnekler verilmiştir. Ayrıca iç geçerlik değerleri için Cohen'in Kappa değerleri hesaplanmıştır. Bu çalışma kullanılan araştırma desen, örnekleme yöntemi ve veri toplama araçları ile sınırlıdır. YÖK tarafından içeriği belirlenen ve araştırmacı tarafından yürütülen Öğretim Teknolojileri dersi de sinırlılıklardan bir diğeridir.

$\mathrm{Bu}$ araştırma, öğretmen adaylarının Öğretim Teknolojileri dersine yönelik görüşlerini belirlemek amacı ile gerçekleştirilmiştir. Söz konusu hedef doğrultusunda Türkiye'de Pamukkale Üniversitesi Eğitim Fakültesinde Psikolojik Danışmanlık ve Rehberlik Anabilim dalında öğrenim görmekte olan 101 öğretmen adayından veriler toplanmıştır. Ulaşılan bulguların, öğretim programında yeni yer bulan Öğretim Teknolojileri dersinin durumunu öğretmen adayları açısından irdeleme bağlamında yararlı olacağı düşünülmektedir. Çalışmada öğretmen adaylarının Öğretim Teknolojileri dersinin içeriği hakkında bilgi sahibi olmadığı belirlenmiştir. Çalışmaya katılan öğretmen adaylarının dersten beklentileri ise ağırlıklı olarak BİT'i öğrenme şeklinde bulunmuştur. Dönem sonunda bu beklentinin katılımcılar tarafindan karşılandığ1 sonucuna ulaşılmıştır. Bunun yanı sıra dersin kendilerine mesleki anlamda katkılarının büyük olduğu öğretmen adayları tarafından belirtilmiştir. Yine bu katkılarda bilgi ve iletişim teknolojilerini etkin kullanma öne çıkan bulgular arasında yer almıştır. Çalışmada yer alan katılımciların büyük bölümünün Öğretim Teknolojileri dersini eksiksiz gördüğü belirlenmiştir. Ancak dersin uygulamalı bir yapısının olmaması eksiklilerden biri olarak bulunmuştur. Buna ek olarak öğretmen adaylarının büyük bölümünün Öğretim Teknolojileri dersini gerekli gördükleri belirlenmiştir. Sonuçların genel olarak eğitimde teknoloji kullanımı konu edinen alanyazın ve Öğretim Teknolojileri dersini odağa alan kısıtlı çalışmalar ile örtüştüğü söylenebilir. Diğer yandan ileride yapılacak araştırmalar ile konunun daha iyi anlaşılmasının gereklilik gösterdiği de gözlenen bir durumdur. Bu bağlamda Öğretim Teknolojileri dersinin bilgi ve iletişim teknolojileri beceresine yönelik etkisinin belirlenebileceği ve bu etkinin nedeninin sorgulanabileceği çalışmalar gerçekleştirilebilir. 